\title{
Spatial demographic inequalities and regional development in Serbia
}

\author{
Suzana Lović Obradović $\bowtie$, Stefana Matović \\ Geographical Institute Jovan Cvijić, Serbian Academy of Science and Art, Belgrade, Serbia; \\ e-mail:s.lovic@gi.sanu.ac.rs
}

\section{ABSTRACT}

The study provides a comprehensive data analysis of demographic and socio-economic characteristics in Serbian regions as factors of uneven regional development. The data were provided by the official population censuses from 1953 to 2011. The study uses the following demographic indicators: population; the index of population change; population density; the share of migrants in the total population; the share of $65+$ population; and the average age of the population. The indicators of the regions' socio-economic development were as follows: the level of development of cities and municipalities; the share of uneducated population; the share of the population with secondary and higher education; the share of welfare recipients; the share of employed population; the share of computer illiterate persons; and the share of the unemployed. The research results have shown significant regional discrepancies: Belgrade, Kosovo and Metohija regions are economically prosperous regions, attractive for migrants from other parts of Serbia, the situation is quite the opposite in Southern and Eastern Serbia, characterized by the outflow of the population and economic underdevelopment, especially in the border areas. The other two regions are within the two extremes, Vojvodina being closer to Belgrade and Šumadija and Western Serbia, to Southern and Eastern Serbia.
\end{abstract}

\section{KEYWORDS}

demographic indicators, socioeconomic indicators, NUTS2 region, regional disparities, Serbia

\section{ACKNOWLEDGMENT}

The study was supported by the Ministry of Education, Science and Technological Development of the Republic of Serbia (project no. 47007).

\section{FOR CITATION}

Lović Obradović S., \& Matović S. (2018) Spatial demographic inequalities and regional development in Serbia. R-economy, 4(3), 88-94. doi: $10.15826 /$ recon.2018.4.3.013

\section{Региональные демографические различия и региональное развитие в Сербии}

\author{
С. Лович-Обрадович $\bowtie$, С. Матович \\ Географический институт «Йован Цвиич» Сербской академии наук, Белград, Сербия; \\ e-mail:s.lovic@gi.sanu.ac.rs
}

\section{PЕЗЮМЕ}

В исследовании содержится всесторонний анализ данных демографических и социально-экономических характеристик сербских регионов, рассмотренных как факторы неравномерного регионального развития. Данные были предоставлены официальными переписями населения с 1953 по 2011 г. В исследовании используются следующие демографические показатели: население; индекс изменения численности населения; плотность населения; доля мигрантов в общей численности населения; доля населения старше 65 лет; и средний возраст населения. Показатели социально-экономического развития регионов были следующими: уровень развития городов и муниципалитетов; доля необразованного населения; доля населения со средним и высшим образованием; доля получателей пособий; доля занятого населения; доля граждан, не умеющих пользоваться компьютерами; и доля безработных. Результаты исследования показали значительные региональные различия: регионы Белград, Косово и Метохия являются экономически процветающими регионами, привлекательными для мигрантов из других районов Сербии, ситуация в Южной и Восточной Сербии является совершенно противоположной, характеризующейся оттоком населения и экономической недоразвитостью, особенно в приграничных районах. Остальные два региона находятся в двух крайностях: Воеводина находится ближе к Белграду, в то время как Шумадия и Западная Сербия - к Южной и Восточной Сербии.

\section{КЛЮЧЕВЫЕ СЛОВА}

демографические показатели, социально-экономические показатели, регион NUTS2, региональные различия, Сербия

\section{БЛАГОДАРНОСТИ}

Исследование было поддержано Министерством образования, науки и технологического развития Республики Сербия (проект № 47007).

\section{ДЛЯ ЦИТИРОВАНИЯ}

Lović Obradović S., \& Matović S. (2018) Spatial demographic inequalities and regional development in Serbia. R-economy, 4(3), 88-94. doi: $10.15826 /$ recon.2018.4.3.013 


\section{Introduction}

The Republic of Serbia has diverse geographical and socio-economic characteristics such as the uneven distribution of the population caused by geographical, social and historical factors. Apart from the pronounced geographical differences, the regions also have different demographic and socio-economic characteristics. The geographical factors had prevailed until the end of the Second World War, and then social factors took over as industrialization led to intensive migration from rural areas to cities. Before that, Serbia had mostly been an agricultural country [1]. The demographic determinant only emphasized the existing differences resulting in significant regional disrepancies. Thus, it is necessary to address the issues of unbalanced population distribution in order to ensure sustainable development of all parts of Serbia [2].

Uneven regional distribution of the population in Serbia is not a new phenomenon. Historically, it goes back to the post-war period of industrialization, when the intensive economic and demographic growth of Belgrade region began. In the same period, southern and eastern Serbia experienced the demographic and economic decline caused by the major disproportions in the country's regional development [3].

Disparities in population concentration and excessive population growth of primary regions can have a negative impact on the country's overall economic development. Therefore, these issues need to be addressed through policies aimed at redirecting the population to other regions; policies promoting investment in infrastructure, marketing, and development of small and medium enterprises [4].

\section{Theoretical framework}

In order to design an adequate policy for balancing regional development it is essential to understand the nature of regional disparities resulting from the unequal distribution of investment and demographic resources. The vast body of literature on the problem of regional disparities and its causes reveals the complexity of this phenomenon. Regional disparities are also among the priority issues in the European Union's policies; most schemes for development and integration of nation states within the EU seek to address this problem as considerable regional disparities are considered to be detrimental for the success of supra-national integration projects (Crudu) [5].
Vorauer (1997) defines regional disparities as a deviation in socio-geographic, economic, social and environmental development within a particular spatial/administrative division resulting in different living standards and unequal economic potential [6]. Kutscheraur et al. (2010) approach regional disparity as a divergence or inequality of characters, phenomena or processes with a specific territorial allocation, occurring in at least two entities of the territorial structure [7]. Tegenu (2011) lists various factors that lead to regional disparities: agro-ecological factors (such as rainfall amount, soil quality, topography and altitude); demographic factors (population density, level of urbanization, reproductive behavior of the households); infrastructure development; income and property; patterns of private investment; and so on. The researcher also points out that the lack of detailed regional studies and inter-regional analysis may contribute to the lack of attention paid to the problem of regional imbalances [8]. However, there is still no generally accepted answer to the question about the origins of regional disparities [9].

Demography places population in the center of research on regional disparities. Vojković (2003) considers that regionalization is a complex phenomenon, which means that population must be viewed in the more general context: we need to look at historical demographic trends, territorial organization of the population, its demographic structure and in particular at the spatial laws which determine the demographic development of a certain area [10]. Population growth can stimulate economic growth, which may attract more migrants, while the loss of population damages the region's economy, thereby reducing the resorces for its further development [11].

\section{Research Methodology and Data}

This study uses the data of seven successive censuses, starting from the first post-war census in 1953 to the last official census in 2011, conducted on the territory of Serbia. In this paper, we provide a comparative overview of the basic demographic indicators for the period of fifty-eight years, placing a special emphasis on the last census. The aim was to point out the complexity of demographic phenomena and processes within the given period. For Kosovo and Metohija, only the data until 1991 were available for analysis as Serbia's Official Statistical Office did not provide official data for this region after 1991. Indicators of regional disparities were divided into two classes - demo- 
graphic and socio-economic. In our analysis we used the following demographic indicators: population; the index of population change; population density; the share of migrants in the total population; the share of $65+$ population; and the average age of the population. To assess the socio-economic development of the region we used the following indicators: the level of development of cities and municipalities; the share of uneducated population; the share of the population with secondary and higher education; the share of welfare recipients; the share of the employed population; the share of computer illiterate persons; and the share of the unemployed.

The indicators were analyzed at the NUTS2 level: in 2011, the Government of the Republic of Serbia adopted the Decree on the Nomenclature of Statistical Territorial Units, which defines the Nomenclature of Statistical Territorial Units, as well as the criteria for grouping of subdivisions of countries on three levels - NUTS 1, NUTS 2 and NUTS 3 (NUTS1 corresponds to groups of regions; NUTS2, regions; and NUTS3, districts). The criteria for NUTS grouping are established according to the EU standards: the population size, geopolitical position, natural potential, the existing territorial organization, and cultural and historical heritage [12]. According to the Decree, Serbia is statistically divided into two large units - Serbia-North and Serbia-South (NUTS 1); five regions (Vojvodina, Belgrade, Šumadija and Western Sebia, Southern and Eastern Serbia and Kosovo and Metohia (NUTS 2)); and 25 districts (NUTS 3) (Figure) [12].

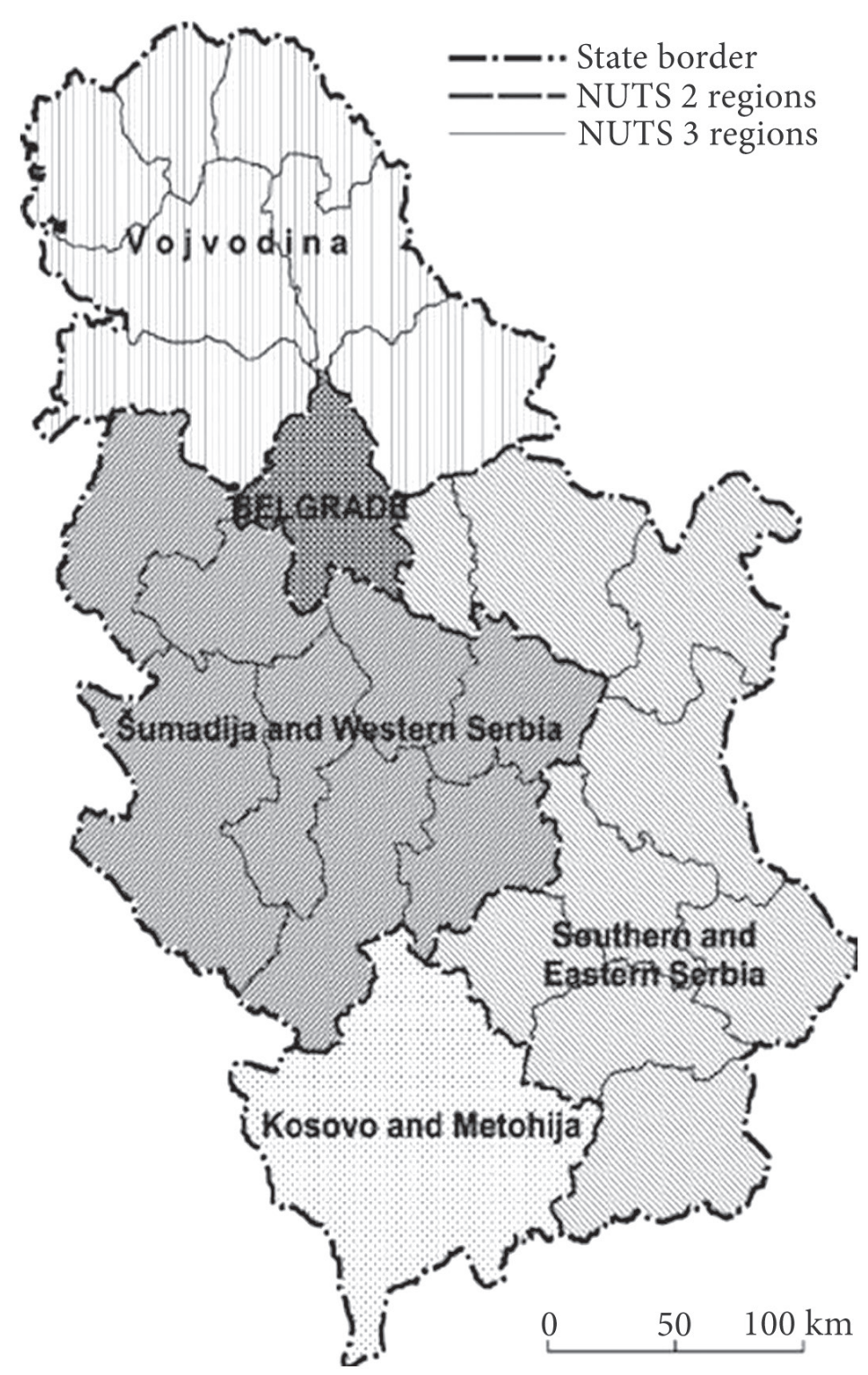

NUTS 2 and NUTS 3 regions in Serbia 


\section{Discussion}

\section{Demographic determinants of regional disparities}

Population size. The available data on the country's population show that the most populated region in Serbia in the given period was Šmadija and Western Serbia. This region is one of the largest in Serbia, which explains its population size (see Table 1). On the other hand, the smallest number of inhabitants was recorded in Belgrade, which is also the smallest. Indices of population change and the data on population density give us a more precise demographic picture of the regions.

Serbian regions are characterized by a diversity of demographic trends. More prosperous municipal centers attract migrants from other regions, which results in unbalanced spatial distribution of the population across Serbia, as the last official census in 2011 showed.

The most economically successful region is Belgrade, which attracts people from all other parts of Serbia. Belgrade is the only region in Serbia in which the share of settled population exceeds $50 \%(51.8 \%)$, while the smallest share is found in Southern and Eastern Serbia (41.2\%). Belgrade attracts the working age population and the reproductive-age population. Although this region shows the highest recorded fertility rates $(10.7 \%)$, there is also a negative natural increase with a rate of $-1.5 \%$. The increase in the number of inhabitants is therefore provided by the positive migration balance.

According to the latest 2011 census, there were 968 settlements with less than 100 inhabitants, and there were also 11 deserted settlements. Serbia is characterized by distinct spatial differentiation in the number of settlements with the population of less than 100 inhabitants. Only one such settlement was found in Belgrade $(0.6 \%)$; in Vojvodina, 12 (2.6\%); in Šumadija and Western Serbia, 128 (14.7\%); in Southern and Eastern Serbia, $827(25.7 \%)$. In the latter region there were also 9 deserted settlements.

Population by age. As in most European countries, in Serbia, for several decades, the birth rates have been insufficient to ensure simple reproduction of the population, which causes depopulation and demographic aging and reflects the consequences of the demographic transition [13]. As far as the number of the elderly is concerned, Serbia is classified as one of the oldest states not only in Europe, but also in the world. Life expectancy rates are increasing and there are much more elderly people than young and active,

Population by regions

Table 1

\begin{tabular}{|c|c|c|c|c|c|c|c|c|c|c|c|c|c|c|c|}
\hline \multirow[t]{2}{*}{ Region } & \multicolumn{8}{|c|}{ Population } & \multicolumn{7}{|c|}{ Index of population change, $1948=100$} \\
\hline & 1948 & 1953 & 1961 & 1971 & 1981 & 1991 & 2002 & 2011 & 1953 & 1961 & 1971 & 1981 & 1991 & 2002 & 2011 \\
\hline Belgrade & 634,003 & 731,837 & 942,190 & $1,209,360$ & $1,470,073$ & $1,602,226$ & $1,576,124$ & $1,659,440$ & 115.40 & 148.60 & 190.70 & 231.90 & 252.70 & 248.60 & 261.70 \\
\hline Urban & 437,053 & 521,114 & 721,183 & 990,272 & $1,206,235$ & $1,310,920$ & $1,274,924$ & $1,344,844$ & 119.20 & 165.00 & 226.60 & 276.00 & 299.90 & 291.70 & 307.70 \\
\hline Other & 196,950 & 210,723 & 221,007 & 219,088 & 263,838 & 291,306 & 301,200 & 314,596 & 107.00 & 112.20 & 111.20 & 134.00 & 147.90 & 152.90 & 159.70 \\
\hline Vojvodina & $1,640,599$ & $1,698,640$ & $1,854,971$ & $1,952,560$ & $2,034,782$ & $2,013,889$ & $2,031,992$ & $1,931,809$ & 103.50 & 113.10 & 119.00 & 124.00 & 122.80 & 123.90 & 117.80 \\
\hline Urban & 655,831 & 699,575 & 826,200 & 978,115 & $1,095,256$ & $1,115,562$ & $1,152,674$ & $1,146,731$ & 106.70 & 126.00 & 149.10 & 167.00 & 170.10 & 175.80 & 174.90 \\
\hline Other & 984,768 & 999,065 & $1,028,771$ & 974,445 & 939,526 & 898,327 & 879,318 & 785,078 & 101.50 & 104.50 & 99.00 & 95.40 & 91.20 & 89.30 & 79.70 \\
\hline $\begin{array}{l}\text { Šumadija } \\
\text { and Wes- } \\
\text { tern Serbia }\end{array}$ & $1,776,544$ & $1,902,934$ & $2,006,793$ & $2,111,855$ & $2,243,885$ & $2,266,428$ & $2,136,881$ & $2,031,697$ & 107.10 & 113.00 & 118.90 & 126.30 & 127.60 & 120.30 & 114.40 \\
\hline Urban & 242,679 & 305,669 & 419,233 & 614,981 & 829,608 & 946,535 & 956,586 & 963,548 & 126.00 & 172.80 & 253.40 & 341.90 & 390.00 & 394.20 & 397.00 \\
\hline Other & $1,533,865$ & $1,597,265$ & $1,587,560$ & $1,496,874$ & $1,414,277$ & $1,319,893$ & $1,180,295$ & $1,068,149$ & 104.10 & 103.50 & 97.60 & 92.20 & 86.10 & 76.90 & 69.60 \\
\hline $\begin{array}{l}\text { Southern } \\
\text { and Eas- } \\
\text { tern Serbia }\end{array}$ & $1,743,691$ & $1,828,910$ & $1,874,293$ & $1,929,140$ & $1,980,506$ & $1,940,252$ & $1,753,004$ & $1,563,916$ & 104.90 & 107.50 & 110.60 & 113.60 & 111.30 & 100.50 & 89.70 \\
\hline Urban & 249,836 & 297,476 & 391,056 & 574,370 & 744,504 & 841,681 & 834,295 & 816,749 & 119.10 & 156.50 & 229.90 & 298.00 & 336.90 & 333.90 & 326.90 \\
\hline Other & $1,493,855$ & $1,531,434$ & $1,483,237$ & $1,354,770$ & $1,236,002$ & $1,098,571$ & 918,709 & 747,167 & 102.50 & 99.30 & 90.70 & 82.70 & 73.50 & 61.50 & 50.00 \\
\hline \begin{tabular}{|} 
Kosovo and \\
Metohija
\end{tabular} & 732,746 & 815,798 & 963,715 & $1,243,811$ & $1,584,440$ & $1,956,196$ & $\ldots$ & $\ldots$ & 111.30 & 131.50 & 169.70 & 216.20 & 267.00 & $\ldots$ & , \\
\hline
\end{tabular}

Source: Statistical Office of the Republic of Serbia (2014). 2011 Census of Population, Households and Dwellings in the Republic of Serbia. Comparative overview of the number of population in 1948, 1953, 1961, 1971, 1981, 1991, 2002 and 2011. Vol. 20. Belgrade: Statistical Office of the Republic of Serbia. Retrieved from: http://pod2.stat.gov.rs/ObjavljenePublikacije/Popis2011/Knjiga20.pdf 
which makes the pension burder heavier [14]. The smallest share of the population older than 65 was recorded in Belgrade and Vojvodina (16.3\%); a slightly higher share was in Šumadija and Western Serbia (17.7\%); and the largest, in Southern and Eastern Serbia, where almost a fifth of the population were older than 65 (19.4\%). In Belgrade, the share of the population aged 65 and older is higher in cities while in other regions, this share is higher in rural areas (Table 2).

The lowest average age of the population was recorded in Belgrade and Vojvodina (41.8 years old); the average age is slightly higher in Šumadija and Western Serbia (42.3 years old); and the oldest population is in Southern and Eastern Serbia (43.3 years old) (see Table 2 ).

\section{Socio-economic determinants of regional disparities}

GDP per capita. The most economically developed regions in Serbia are Belgrade and Vojvo- dina with the GDP per capita above the national average. Šumadija and Western Serbia, Southern and Eastern Serbia with Kosovo and Metohija have the GDP level below the national average, and belong to the group of underdeveloped regions.

Education. The level of education shows regional disparities. Belgrade has the smalest share of uneducated people in the total population $(1.2 \%)$ and at the same time the largest share of population with secondary and higher education (27.8\%). Southern and Eastern Serbia is characterized by the largest share of uneducated population (12.5\%) and the smalest share of the population with secondary and higher education (3.8\%) (see Table 2).

Social welfare and employment. There are considerable regional disparities in the share of welfare recipients and in the share of employed people. The lowest share of the former is in Belgrade, while the largest share of the latter is characteristic of Southern and Eastern Serbia (see Table 2).

Table 2

Demographic and socio-economic indicators

\begin{tabular}{|c|c|c|c|c|c|c|c|c|c|}
\hline Region & $\begin{array}{c}\text { The } \\
\text { share of } \\
\text { migrants } \\
(\%)\end{array}$ & $\begin{array}{c}\text { The share of } \\
\text { population } \\
65 \text { and over } \\
(\%)\end{array}$ & $\begin{array}{c}\text { Average } \\
\text { age }\end{array}$ & $\begin{array}{l}\text { The share } \\
\text { of uned- } \\
\text { ucated } \\
\text { popula- } \\
\text { tion (\%) }\end{array}$ & $\begin{array}{l}\text { The share of } \\
\text { population } \\
\text { with second- } \\
\text { ary and higher } \\
\text { education (\%) }\end{array}$ & $\begin{array}{c}\text { The share } \\
\text { of welfare } \\
\text { recipients } \\
\text { (\%) }\end{array}$ & \begin{tabular}{|c|} 
The \\
share of \\
employed \\
popula- \\
tion $(\%)$ \\
\end{tabular} & $\begin{array}{l}\text { The share } \\
\text { of comput- } \\
\text { er iliterate } \\
\text { population } \\
(\%)\end{array}$ & $\begin{array}{l}\text { The share } \\
\text { of unem- } \\
\text { ployed } \\
\text { popula- } \\
\text { tion (\%) }\end{array}$ \\
\hline Belgrade & 51.8 & 16.4 & 41.8 & 1.2 & 27.8 & 0.9 & 35.3 & 38 & 7.8 \\
\hline Urban & - & 16.5 & 41.9 & 0.9 & 32.1 & 0.8 & 36.2 & 33.9 & 8.9 \\
\hline Other & - & 15.8 & 41.4 & 2.46 & 9.3 & 1.3 & 31.2 & 56 & 6.8 \\
\hline Vojvodina & 46.2 & 16.4 & 41.8 & 2.3 & 14.1 & 2.6 & 30 & 49.3 & 9.2 \\
\hline Urban & - & 15.8 & 41.4 & 1.58 & 19.1 & 2 & 32 & 42.1 & 10.8 \\
\hline Other & - & 17.3 & 42.3 & 3.41 & 6.7 & 3.4 & 27.1 & 59.7 & 7.7 \\
\hline $\begin{array}{l}\text { Šumadija and } \\
\text { West Serbia }\end{array}$ & 41.3 & 17.7 & 42.3 & 3.4 & 11.7 & 2.1 & 30 & 57.4 & 9.2 \\
\hline Urban & - & 14.5 & 40.6 & 1.6 & 18.6 & 2 & 32 & 44.3 & 10.1 \\
\hline Other & - & 20.6 & 43.7 & 4.9 & 5.5 & 2.1 & 27.1 & 69 & 8.3 \\
\hline $\begin{array}{l}\text { South and } \\
\text { East Serbia }\end{array}$ & 41.2 & 19.4 & 43.3 & 3.7 & 12.5 & 2.3 & 28.5 & 58.7 & 11 \\
\hline Urban & - & 15 & 41 & 2.1 & 20.8 & 2.6 & 30 & 46.3 & 12.1 \\
\hline Other & - & 24.1 & 45.7 & 5.5 & 4.9 & 2.3 & 27.2 & 72 & 9.9 \\
\hline
\end{tabular}

Source: Statistical Office of the Republic of Serbia (2013). 2011 Census of Population, Households and Dwellings in the Republic of Serbia. Educational Attainment, Literacy and Computer Literacy. Vol. 3. Belgrade: Statistical Office of the Republic of Serbia. Retrieved from: http://pod2.stat.gov.rs/ObjavljenePublikacije/Popis2011/Skolska\%20sprema,\%20pismenost\%20i\%20 kompjuterska\%20pismenost-Educational\%20attainment, $\% 20$ literacy\%20and\%20computer\%20literacy\%20.pdf; Statistical Office of the Republic of Serbia (2013). 2011 Census of Population, Households and Dwellings in the Republic of Serbia. Migrations. Vol. 9. Belgrade: Statistical Office of the Republic of Serbia. Retrieved from: http://pod2.stat.gov.rs/ObjavljenePublikacije/Popis2011/Knjiga\%209 Migracije-Migrations.pdf; lgrade: Statistical Office of the Republic of Serbia. Retrieved from: http://pod2.stat. gov.rs/ObjavljenePublikacije/Popis2011/Knjiga20.pdf; Statistical Office of the Republic of Serbia (2014). 2011 Census of Population, Households and Dwellings in the Republic of Serbia. Population. Economic activity. Vol. 19. Belgrade: Statistical Office of the Republic of Serbia. Retrieved from: http://pod2.stat.gov.rs/ObjavljenePublikacije/Popis2011/Knjiga\%207 Ekonomska\%20 aktivnost-Economic\%20activity.pdf 
Computer literacy and economic activity. When it comes to the share of computer illiterate people and the share of unemployed in the total population, the smalest share of people of both categories is in Belgrade, and the largest, in Southern and Eastern Serbia (see Table 2).

\section{Conclusion}

Since there is a correlation between spatial/ regional inequalities and economic growth, more attention should be paid to the question about the connection between the demographic and economic forms of regional inequality as well as other forms, such as social, ethnic, political, religious, and so on [15]. Drawing upon the available census data, this paper sought to examine the influence of spatial demographic inequalities on regional development. While Belgrade, Kosovo and Metohija (till 1981) are economically prosperous regions, attractive for migrants from other parts of Serbia, the situation is quite the opposite in Southern and Eastern Serbia, characterized by the outflow of the population and economic underdevelopment, especially in the border areas. The other two regions are within the two extremes, Vojvodina being closer to Belgrade, and Šumadija and Western Serbia closer to Southern and Eastern Serbia.

In the given period, Belgrade and Kosovo-Metohija were singled out as growth poles. In Belgrade, however, the population increase is largely determined by the positive migration balance: as the city is a political, administrative, educational and economic center, it attracts migrants from all other parts of Serbia. The increase in the number of inhabitants in Kosovo and Metohija was due to the positive natural increase. Southern and Eastern Serbia was a negative pole of growth, with a marked demographic decline, as the last two censuses have demonstrated. A significant decline in population, especially in other (rural) settlements, shows that the old mechanisms of demographic growth are no longer effective. Given the negative demographic trends, which are reflected in the negative natural increase and emigration, as a consequence of the historically determined unfavorable age structure of the population, a further decline in the population is expected.

\section{References}

1. Vojković, G. \& Kokotović, V. (2009). The Roll of Small and Medium Size Towns in Polycentric Development of Serbia - Demographic Aspects, In: Stamenković, S. (Eds.). Territorial Aspects of Development of Serbia and Neighboring Countries. Beograd: University of Belgrade, Faculty of Geography.

2. Stojanović, J., Kokotović Kanazir V. \& Stojanović M. (2017). Does a Small Town with a Touristic Function Have Demographic Potential. J. Geogr. Inst. Cvijić, 67(2), 145-162. doi: 10.2298/ijgi1702145s

3. Vojković, G., Kokotović, V. \& Spalević, A. (2012). Demografska održivost naseljskog sistema Jugoistočne Srbije. In: Ljubiša Mitrović (Eds.). Stanovništvo Jugoistočne Srbije: Uticaj Demografskih Promena u Jugoistočnoj Srbiji na Društveni Razvoj i bezbednost. Niš: Centar za naučno-istraživački rad SANU i Univerziteta u Nišu.

4. Rondinelli, D. A. (1985). Population Distribution and Economic Development in Africa: The Need for Urbanization Policies. Population Research and Policy Review, 4(2), 173-196.

5. Crudu, R. (2015). Economic Crisis and Economic Disparities in European Union. Centre for European Studies (CES). Working Papers, 7(2A), 420-433. Retrieved from http://ceswp.uaic.ro/articles/CESWP2015 VII2A CRU.pdf

6. Vorauer, K. (1997). Europäische Regionalpolitik Regionale Disparitäten: Theoretische Fundierung, Empirische Befunde und Politische Entwürfe. Passau: Münchener Geographische Hefte.

7. Kutscherauer A., Fachinelli, H., Hučka, M., Skokan, K., Sucháček, J., Tománek, P., \& Tuleja, P. (2010). Regional Disparities: Disparities in Country Regional Development - Concept, Theory, Identification and Assessment. Ostrava: VŠB-Technical University of Ostrava. Retrieved from http://disparity.idealnihosting.cz/edice_cd/cd11_regdis_mono_angl/pdf/Regional\%20disparities.pdf

8. Tegenu, T. (2011). Population Pressure and Regional Development Disparities in Ethiopia: Case of Southern Region. Retrieved from https://www.diva-portal.org/smash/get/diva2:938642/FULLTEXT01.pdf 
9. Ocić, Č. (2005). Regional disparities in Yugoslavia from 1952 to 1988. Megatrend Review, 2(1), 5-42.

10. Vojković, G. (2003). Stanovništvo kao element regionalizacije Srbije (Population as an element of regionalization of Serbia). Stanovništvo, 41(1-4), 7-42. doi: 10.2298/stnv0304007v

11. Combes, M. (2010). Migration and Regional Development: a Research Review. Paper Presented at the OECD WPTI Workshop, Paris, June 7, 2010. Retrieved from http://www.oecd.org/cfe/ regional-policy/45522500.pdf

12. Uredba o Utvrđivanju Jedinstvene Liste Razvijenosti Regiona i Jedinica Lokalne Samouprave za 2014 godinu (Službeni glasnik RS, br. 104/2014). Retrieved from http://ras.gov.rs/uploads/2017/03/podrska\%20za\%20otvaranje\%20novih\%20radnih\%20mesta/Lista\%20razvijenosti\%20JLS.pdf

13. Kokotović Kanazir, V., Stojilković Gnjatović, J., Filipović, M., Babović, S., Ivković, M. \& Lović Obradović, S. (2017). Stanovništvo. In: M. Radovanović (Eds.). Geografija Srbije. Beograd: Geografski institut „Jovan Cvijićc SANU.

14. Lović Obradović, S., Babović, S., \& Shpak, N. (2016). Serbia and Russia on the Demographic Map of Europe Two Decades after the Fall of Communism. Trames, 20(1), 59-73. doi: 10.3176/ $\underline{\operatorname{tr} .2016 .1 .04}$

15. Molnar, D. S. (2013). Regional Inequalities and Economic Growth: The Example of Serbia (Doctoral dissertation). Retrieved from http://nardus.mpn.gov.rs/handle/123456789/2223?locale-at$\underline{\text { tribute }=\text { sr } R S}$

\section{Information about the authors}

Suzana Lović Obradović - Research Associate, Geographical Institute Jovan Cvijić, Serbian Academy of Science and Art (9 Đure Jakšića St., 11000 Belgrade, Serbia); e-mail: s.lovic@gi.sanu.ac.rs.

Stefana Matović - Research Associate, Geographical Institute Jovan Cvijić, Serbian Academy of Science and Art (9 Đure Jakšića St., 11000 Belgrade, Serbia). 